JOURNAL OF SECURITY AND SUSTAINABILITY ISSUES

ISSN 2029-7017 print/ISSN 2029-7025 online

2019 March Volume 8 Number 3

http://doi.org/10.9770/jssi.2019.8.3(2)

\title{
Scopus
}

\section{EVALUATION OF THE ENERGY SECURITY AS A COMPONENT OF NATIONAL SECURITY OF THE COUNTRY}

\author{
Henryk Dźwigoł ${ }^{1}$, Mariola Dźwigoł-Barosz ${ }^{2}$, Zinaida Zhyvko³ ${ }^{3}$ Radosław Miśkiewicz $^{4}$, Halyna Pushak $^{5}$ \\ 1,2,4 Silesian University of Technology, Roosevelta Street 26, 41-800 Zabrze, Poland \\ $3^{3}$ Lviv State University of Internal Affairs, Gorodotska str., 26, Lviv, Lviv region, 79000,Ukraine \\ ${ }_{5}^{5}$ Lviv Polytechnic National University, Room 502, Building 4, Mytropolyt Andrei Street, Lviv,79013,Ukraine \\ E-mail: ${ }^{3 *}$ koaduep@gmail.com
}

Received 15 March 2018; accepted 20 January 2019; published 30 March 2019

\begin{abstract}
The methodical approach to the integrated evaluation of the energy independence of the country and its regions has been improved based on the multidimensional mean, which includes the selection of statistical indicators, the choice of the base of their normalization, the use of the analytic hierarchy process for evaluation of weighting coefficients and the method of aggregation of indicators in the integrated evaluation of energy independence. Using the coverage ratio of consumption with the production of fuel and energy resources, the state of energy dependence has been analyzed for some world countries, which have successes in conducting the energy policy and experience of which should be implemented in the national strategy for the development of the energy complex. The calculation of integral indicators of energy independence for each region will make it possible to determine the "strong" and "weak" regions in the energy sector, identify the reasons of lagging of the most "energy-dependent" areas, and develop appropriate recommendations for improving energy independence for each region.
\end{abstract}

Keywords: national security, energy independence, energy complex, energy intensity of production, energy security, integrated evaluation

Reference to this paper should be made as follows: Dźwigoł, H.; Dźwigoł-Barosz, M.; Zhyvko, Z.; Miśkiewicz, R.; Pushak, H. (2019). Evaluation of the energy security as a component of national security of the country, Journal of Security and Sustainability Issues 8(3): 307-317. http://doi.org/10.9770/jssi.2019.8.3(2)

JEL Classifications: F52, O39

\section{Introduction}

The most important conditions for the stable and proportional development of the state are solving problems of energy intensity of production and energy supply of the economy, the failure to fulfil which is a threat to economic and national security.

The success of a policy of energy efficiency depends on scientifically based economical and statistical analysis, forecasting and optimization of the state's energy balance. The fuel and energy complex, its state, opportunities and prospects of development, the effectiveness of the state energy policy significantly affect the economic situation in the country and the conditions for its sustainable development.

The general processes of integration of the country's economy and energetics into world and European structures considerably increase the requirements for ensuring its energy security and energy independence. Therefore, the factor of energy independence as a country's ability to independently formulate and implement a policy independent from external and internal interference and pressure becomes of particular importance as one of the main elements of ensuring energy, economic and national security, economic and political independence. 
The problem of achieving energy independence is one of the main tasks of many countries of the world. The development and optimal functioning of the fuel and energy complex of the state is one of the main factors in ensuring the effective functioning of the economy and meeting the social needs of the population, which determines the relevance of this topic.

The problems of ensuring national security and its main components such as economic and energy securities are the subject of research in the works of scientists of various fields of knowledge: economists and political experts, specialists in energy production and lawyers, military and public administration specialists.

The energy security has an integral nature and is a complex category, on which the normal functioning and development of the state and society depend. It includes the following components:

1) energy supply (economic component);

2) social stability;

3) ecological suitability (ecological component);

4) energy independence (political and economic component).

Energy supply (economic component) characterizes the state of fuel and energy supply of the national economy and population. This condition depends on the adequacy, reliability, quality of deliveries, as well as on the efficiency of energy production and energy consumption. Social instability characterizes the social tensions in a country related to energy supply. Ecological suitability is characterized by the state of pollution of the environment by the objects of energy production and transport of energy carriers (oil and gas pipelines) and the possibility of reimbursement of the ecological and economic damage caused to the environment.

\section{Literature Survey}

According to the author's content analysis, it is stated that an effective energy policy should cover:

- development and implementation of a transparent and effective legal and regulatory framework for the functioning of all energy sectors, which envisages regulation, coordination and control over the activities of state energy systems, nuclear power and natural monopolies (Aitzhan, N. Z., \& Svetinovic, D. (2018)); creation of economic conditions for energy supply to domestic and foreign markets (Biresselioglu, M. E., Yelkenci, T., Ozyorulmaz, E., \& Yumurtaci, I. Ö. (2017));

- effective management of strategic reserves of energy resources, which includes: diversification of energy resources supply, prevention of inefficient use of energy resources, harmonization of the rates of consumption of exhaustible resources with the rates of development of renewable energy resources, increase of the part of atomic power industry and hydropower in the overall balance of FER, quality control and ecological safety of mineral deposits for compliance with the requirements of the legislation and international standards (Bakhtiyari, Z., Yazdanpanah, M., Forouzani, M., \& Kazemi, N. (2017); Rogalev, A., Komarov, I., Kindra, V., Zlyvk, O. (2018); Smaliukiene, R.; Monni, S. (2019));

- implementation of investment policy in the national energy sector, which envisages modernization of the outdated technological base of the fuel and energy complex, expansion of the infrastructure of scientific, engineering and technical support and maintenance of complex equipment of the power industry (GarcíaGusano, D., Iribarren, D., \& Garraín, D. (2017));

- establishment of technical regulations and the development of standards and targets for the safety and efficiency of the operation of power facilities and installations, as well as the development of a mechanism for state supervision of their compliance (Kirshner, J. (2018)).

Industry is driven by energy production, which provides vital functions of the state, as well as guarantees its security and independence. Energy production is a vital component of the world economy. In the world economy there is an active process of rising cost of energy resources (oil, gas, coal). This is primarily due to the sharp increase in the consumption of hydrocarbon energy by industrialized countries such as the USA, Japan, Germany, as well as the significant development of the economy of China, India and other countries of the world. All this in aggregate determines the search for energy-saving technology and technology in the world economy. 


\section{Methods}

The modern theory of the development of the world economy states that the role and international situation of the countries of the world is determined not only by the availability of natural resources (oil, gas), but also intellectual potential, the ability to implement innovative advances in scientific and technological progress.

Statistical analysis of data, including the energy sector, becomes an integral attribute of the management system at all its levels - from a small firm to a national economy as a whole. Statistical models are used to diagnose the state of objects of management, in studying the causal mechanism of the formation of variation and dynamics of socio-economic phenomena and processes, in monitoring economic conditions, in forecasting and optimal managerial decision making (Gil'orme, T., Ryzhyk, Y., \& Yaresko, A. (2016); Pająk, K., Kvilinskyi, O., Fasiecka, O., Miśkiewicz, R. (2017)).

Growth curves describing the regularities of development of the phenomenon are obtained by analytical alignment of time series. Alignment of time series with the help of some or other functions in most cases is a convenient approach of describing empirical data, characterizing the development of the phenomenon in time. The obtained models, taking into account a number of conditions, can be applied for prediction purposes.

The process of alignment of time series consists of two main stages: the choice of the type of the curve, the shape of which corresponds to the nature of the change in time series or type of growth process; definition of numerical values (evaluation) of curve parameters. The found function allows one to get aligned or, as they are sometimes called, the theoretical values of levels of time series. This function is also used for extrapolation. The question of choosing the type of curve is fundamental when aligning time series. In all other equal conditions, the error in choosing the form of the growth curve in solving the problem is more significant in its consequences (especially for forecasting) than the error associated with the statistical evaluation of parameters (Augutis, J., Krikštolaitis, R., Martišauskas, L., Pečiulytè, S., \& Žutautaitè, I. (2017)).

Adaptive methods of modelling and forecasting are based on maintaining the rigidity of development, but taking into account the factor of "outdated" data, in other words, the model is adapted with the help of special parameters to the conditions formed at each instant. They make it possible to construct self-regulating models which are able both to respond promptly to changing conditions and on this basis to make in the near future more accurate forecasts, taking into account the result of the forecast (or aligning) made in the previous step and the different informational value of the components of time series (Radovanović, M., Filipović, S., \& Pavlović, D. (2017); Mazurkiewicz, J., Lis, P. (2015)).

The range of application of statistical methods in managerial activity is quite wide. This, first of all, concerns the preparation of information, its analysis, comparison with the relevant criteria, and on this basis, the identification of problems and ways of their solution on the basis of practical analysis. Statistical methods are used at the stage of implementation of managerial decisions, while monitoring their implementation and assessing the effectiveness of the results obtained (Glynn, J., Chiodi, A., \& Gallachóir, B. Ó. (2017)).

Therefore, statistical provision of regulation of energy independence is to form an analytical basis for making managerial decisions that captures the efficiency of energy use, dependence on imports from other countries, estimates the dynamics and trends of energy consumption and production, predicts possible changes in future periods, and also estimates the potential for increasing energy independence of the country (Su, M., Zhang, M., Lu, W., Chang, X., Chen, B., Liu, G., ... \& Zhang, Y. (2017)).

Objects to which the statistical provision of regulation of energy independence is directed are those phenomena and processes of the energy sector that require the implementation of transformations (Nakashydze, L., \& Gil'orme, T. (2015); Lakhno, V., Malyukov, V., Bochulia, T., Hipters, Z., Kwilinski, A. \& Tomashevska, O. (2018)). Such phenomena and processes are the production and consumption of FER, FER imports, FER efficiency, FER structure, investment inflows into the energy sector, etc. The research of the objects of statistical regulation of energy independence in the complex will reveal the weaknesses and strengths of the national energy sector 
(Nitibaskara, T. R. R., Herdiansyah, H., \& Sari, R. (2017)).

The statistical study of the energy independence of the country involves the use of the following statistical research methods:

- method of summarizing indicators (allows one to evaluate the efficiency of FER use in the economy, to identify the weaknesses of enterprises and organizations, which slow down the further development of the energy situation in the country, and to develop the necessary measures for their elimination) (Bompard, E., Carpignano, A., Erriquez, M., Grosso, D., Pession, M., \& Profumo, F. (2017))

- analysis of time series - reveals the trends and dependencies of production and consumption of FER in the production of products and services, allowing one to understand the reasons of adverse events and to develop proper solutions (Cox, E. (2018)).

\section{Results}

The analysis of time series enables to model time series and calculate perspective evaluations of indicators. Among the classes of models, one should distinguish trend models (linear, parabolic, power, exponential, hyperbolic, logarithmic one), adaptive models (exponential smoothing, linear and parabolic Brown models, Hellwig method), autoregressive models (with lags of delay, the Box-Jenkins model and generalized linear time series models).

An element of development of statistical provision of regulation of energy independence of the country is the formation of research directions (Table 1).

Table 1. Research directions of energy independence of the country

\begin{tabular}{|l|c|}
\hline \multicolumn{1}{|c|}{ Research directions of energy independence } & $\begin{array}{c}\text { Statistical methods and models used } \\
\text { for the analysis of energy independence }\end{array}$ \\
\hline $\begin{array}{l}\text { Macroeconomic analysis of the country's energy dependence situation: } \\
\text { - analysis of volumes and structure of production and consumption of } \\
\text { energy resources, all and including for different types of resources; } \\
\text { - analysis of the effectiveness of FER use in the country. }\end{array}$ & $\begin{array}{c}\text { Method of aggregated analytical indicators of structure, } \\
\text { series, comparison, intensity }\end{array}$ \\
\hline $\begin{array}{l}\text { Evaluation of energy independence level in the regions and analysis of } \\
\text { series of the integral indicator in the whole country }\end{array}$ & $\begin{array}{c}\text { Relative intensities, the method of multidimensional mean, } \\
\text { the use of statistical methods groups }\end{array}$ \\
\hline $\begin{array}{l}\text { Evaluation of monopoly level in the market of energy services } \\
\text { economic indicators }\end{array}$ & $\begin{array}{c}\text { Herfindahl-Hirschman index } \\
\text { Prospective evaluation of the country's energy independence level }\end{array}$ \\
\hline $\begin{array}{l}\text { Evaluation of interconnections of FER consumption with other socio- } \\
\text { regresion analysis }\end{array}$ \\
\hline
\end{tabular}

The proposed directions of the study of energy independence will allow one to comprehensively and qualitatively analysis the current state of the energy complex, identify certain regularities, trends, interconnections, provide predictive values of the key indicators of the energy sector, draw conclusions about the prospects of achieving energy independence of the country and develop effective recommendations for improvement of the situation.

Implementing an effective energy policy, attracting investment, developing alternative energy, optimizing the regulatory framework will contribute to the development of the energy sector of the country, which will reduce the volumes of energy borrowing from other countries, increase the efficiency of their use and, accordingly, achieve an acceptable level of energy independence of the country.

One of the main determinants of the sustainable functioning of the energy complex is the mismatch of FER consumption and production. In order to analysis the given determinants, a new indicator is proposed - the coverage ratio of FER consumption with the production.

If this ratio is more than $100 \%$, this means the country can fully provide the population and the economy as a 
whole in energy, while it will have savings in the form of FER, which can be sent for export. If the ratio is equal to $100 \%$, this indicates a complete supply of energy to the country without the possibility of saving it. The ratio of less than $100 \%$ suggests the country's need to import energy resources to meet the needs of the population and the economy.

The coverage ratio that is suitable for comparative analysis for some world countries is given in Table 2. For comparison, countries that have success in energy policy and whose experience needs to be implemented in the national energy development strategy are selected.

Table 2. Dynamics of coverage ratio of FER consumption with the production (author's calculations based on (Global Energy Statistical Yearbook (2017)))

\begin{tabular}{|c|c|c|c|c|c|c|c|}
\hline \multirow{2}{*}{ Country } & \multicolumn{7}{|c|}{ Coverage ratio, \% } \\
\cline { 2 - 7 } & 2011 & 2012 & 2013 & 2014 & 2015 & 2016 & 2017 \\
\hline Russia & 180,1 & 178,0 & 185,0 & 182,2 & 188,1 & 191,6 & 190,6 \\
\hline China & 87,6 & 85,1 & 84,7 & 84,5 & 83,9 & 80,9 & 80,5 \\
\hline USA & 81,5 & 84,4 & 86,1 & 90,8 & 82,3 & 88,3 & 91,7 \\
\hline Czech Republic & 74,9 & 75,5 & 70,8 & 71,1 & 68,9 & 67,3 & 65,9 \\
\hline Poland & 67,6 & 73,2 & 72,9 & 71,8 & 71,6 & 69,2 & 61,6 \\
\hline Sweden & 66,7 & 72,1 & 71,0 & 71,7 & 74,8 & 72,4 & 74,7 \\
\hline Germany & 39,6 & 39,5 & 37,9 & 39,2 & 38,9 & 37,4 & 38,7 \\
\hline
\end{tabular}

Among the represented countries, only the Russian Federation is able to fully provide its economy with energy resources (in 2017 the coverage ratio was 190.6\%) and to export energy and energy resources to other countries. Today, Russia is the world's largest exporter of FER, in particular, electricity, natural gas, and oil. At the same time, Germany has the worst coverage ratios of FER consumption with the production. In 2017, the FER consumption is covered by its own production only by $38.7 \%$, which indicates the import dependence on energy resources from other countries.

Providing tools for regulating energy independence is a complex political, economic, socio-economic, and scientific problem that, for its solution, requires comprehensive research on a wide range of issues. One of these issues is to determine the quantitative characteristics of probable threats and determine their influence on the level of energy independence of the country.

As the characteristics of the level of energy independence in the regions, economic indicators that determine the potential for energy independence are used, among which the following are highlighted:

1) energy intensity of production (x1). FER energy intensity is a general macroeconomic indicator that characterizes the level of FER costs per unit of produced GRP, one of the fundamental characteristics of the energy efficiency of the economy as a region and the country as a whole (Valdés, J. (2018)).

2) export (x2), import (x3) of energy products and part of FER import in the total volume of import of goods (x4). Foreign FER trade is one of the main factors in the development of the energy complex. That is why these factors were included in the calculation of the integral indicator.

3) the analysis of the state and development of the energy sector by regions is impossible without determining FER consumption in each of them, since the level of energy efficiency of the region depends on the level of this indicator. Since the regions are characterized by different population size, which affects the level of FER consumption, for the purpose of comparability of the data in the work, the indicator of total FER consumption per capita (x5) is proposed.

4) the important role in the determination of integral indicator is the volume of sales of mineral industry and quarry development (x6). Mining and quarry development involves mining of minerals found naturally in the form of solid rock (coal and ore), in liquid (oil) and gaseous state (natural gas). 
Table 3. Factors for integrated evaluation of the energy independence of the regions of the country

\begin{tabular}{|l|c|}
\hline \multicolumn{1}{|c|}{ Indicators of the energy sector } & $\begin{array}{c}\text { Indicator distribution depending on the influence } \\
\text { on the level of energy independence of the region } \\
\text { (incentive/disincentive) }\end{array}$ \\
\hline Energy intensity of production & Disincentive \\
\hline Export of mineral fuel, oil and products of its distillation & Incentive \\
\hline Import of mineral fuel, oil and products of its distillation & Disincentive \\
\hline Part of FER import in the total volume of import of goods & Disincentive \\
\hline FER consumption per capita & Disincentive \\
\hline Volume of sales of mineral industry and quarry development per capita & Incentive \\
\hline
\end{tabular}

In studying socio-economic phenomena at the macro level, one often uses groups, intervals of which are randomly constructed, therefore, based on the research results, the following groups were identified by the level of energy independence of the regions: up to 0.4000 - extremely low level of energy independence (problem regions); 0,4001-0,5500 - low level of energy independence; 0,5501-0,6000 - middle level (promising regions); more than 0,6001 - high level of energy independence (regions-leaders).

In line with the level of energy independence of the regions, appropriate measures are being taken to improve the state of the energy sector. The volume of FER consumption in the country is determined by a number of factors, among which the most significant is the dollar exchange rate, because it generates state expenditures on FER imported, which are not enough in the country to meet the needs of the economy and population; capital investments, since they characterize the technical level of production, the level of energy conservation and energy efficiency; the index of physical volume of GDP, since the amount of energy consumed depends on the volumes of social production; FER production, the amount of which depends on the level of savings in FER consumption. Therefore, the influence of these factors on FER consumption in the country is studied in the paper.

In the same way at the macro level we allocate such indicators of energy independence (Table 4).

Table 4. Indicators of energy independence

\begin{tabular}{|l|c|}
\hline \multicolumn{1}{|c|}{ Indicator } & $\begin{array}{c}\text { The influence on energy } \\
\text { independence }\end{array}$ \\
\hline GDP per capita, USD / person & Incentive \\
\hline Production of energy materials, thousands of tons & Incentive \\
\hline Export of energy products, thousand USD & Incentive \\
\hline $\begin{array}{l}\text { Investments in fixed capital for type of economic activity “Electric power, gas, vapour, and conditioned } \\
\text { air supply", million USD }\end{array}$ & Incentive \\
\hline $\begin{array}{l}\text { The volume of industrial products sold as a type of economic activity “Electric power, gas, vapour, and } \\
\text { conditioned air supply", million USD }\end{array}$ & Incentive \\
\hline Total FER consumption in the country, millions of tons of conventional fuel & Disincentive \\
\hline Energy intensity of production, tons of conventional fuel /1000 USD & Disincentive \\
\hline The level of FER import to GDP, $\%$ & Disincentive \\
\hline $\begin{array}{l}\text { Import of energy products, million USD } \\
\text { The degree of wear of fixed-capital assets by type of economic activity “Electric power, gas, vapour, and } \\
\text { conditioned air supply", } \%\end{array}$ & Disincentive \\
\hline Specific gravity of natural gas in the structure of FER consumption, $\%$ & Disincentive \\
\hline
\end{tabular}

The state and development of the level of energy independence of the country includes various socio-economic indicators, which cannot be uniquely evaluated, therefore, a multidimensional mean method is used for the comprehensive evaluation of energy independence. Multidimensional groups allow developing an integrated evaluation of such a complicated category as energy independence. It monitors the overall orientation of the country's energy independence as a whole, enabling comprehensive research into the dynamics of energy 
development and the identification of factors that adversely affect energy independence and, accordingly, require managerial intervention from both the enterprises and the state as a whole to effectively implement the necessary measures; The multidimensional mean method also makes it possible to grade and group regions by the integral level of energy independence.

In order to improve the quality of the results of the study, the weight of each factor using the analytic hierarchy process (AHP) is calculated. The established evaluations were based on the next ratio scale (Table 5), proposed by Thomas L. Saaty, the AHP founder.

Table 5. Ratio scale

\begin{tabular}{|c|c|c|}
\hline Weight & Evaluation & Characteristics of advantages \\
\hline 1 & Same weight & $\begin{array}{c}\text { Equivalent value, that is, two judgments make the same } \\
\text { contribution to the achievement of the goal }\end{array}$ \\
\hline 3 & $\begin{array}{c}\text { Some weight advantage of one judgment } \\
\text { over another (weak weight) }\end{array}$ & $\begin{array}{c}\text { There are insights in favour of the advantage of one judgment } \\
\text { over another, but these insights are not sufficiently convincing }\end{array}$ \\
\hline 5 & Considerable or significant weight & $\begin{array}{c}\text { There are scientific data or logical judgments (or own feelings) } \\
\text { about the advantage of one judgment over another }\end{array}$ \\
\hline 7 & Obvious or very significant weight & Absolute weight \\
\hline $2,4,6,8$ & $\begin{array}{c}\text { Intermediate values between } \\
\text { two adjacent judgments }\end{array}$ & $\begin{array}{c}\text { Evidence or feeling in favour of the advantage } \\
\text { of one judgment over another is most convincing }\end{array}$ \\
\hline $\begin{array}{c}\text { Reverse values of } \\
\text { reduced non-zero } \\
\text { values }\end{array}$ & $\begin{array}{c}1 / 2,1 / 3,1 / 4, \text { etc. are assigned for symmetric } \\
\text { (in relation to the diagonal) ratios }\end{array}$ & $\begin{array}{c}\text { Significance of judgments are less } \\
\text { significant of that compared to it }\end{array}$ \\
\hline
\end{tabular}

The complexity of calculating the integrated evaluation of energy independence of regions requires wide application of expert evaluations in the process of forming and choosing solutions. Expert evaluations as a way of obtaining information have always been used in decision making, since using information from experts in a particular industry is very useful.

The principle of method of expert evaluations is the rational organization by experts the analysis of the problem with the quantitative evaluation of judgments and the processing of their results. The general opinion of the expert group is taken as a solution to the problem. The probability of an expert group's evaluation depends on the level of knowledge of individual experts and the number of members (Tetiana, H., Chorna M., Karpenko L., Milyavskiy M. \& Drobyazko S. (2018)). With AHP, which allows one to make the right managerial decision, it is possible to select the most significant indicators of the integral indicator of energy independence. AHP is used to solve multicriteria problems under uncertainty. According to this method, the choice of priority solutions is carried out using pair comparisons. AHP is based on the principle of identity and decomposition, contains procedures for synthesizing multiple statements, obtaining priority criteria and finding alternative solutions (Tetiana, H., Karpenko, L., Fedoruk, O., Shevchenko, I., \& Drobyazko, S. (2018); Karpenko, L., Serbov, M., Kwilinski, A., Makedon, V. \& Drobyazko, S. (2018)).

\section{Discussion}

The country's energy independence requires quantitative evaluation to ensure regulatory actions in this area of government activity. In order to do this, it is necessary to highlight the most significant both absolute and relative indicators, which evaluate the country's energy independence. At the stage of formation of the attribute space, a priori qualitative analysis of the essence of the phenomenon plays a crucial role. When forming the information space it is important to ensure the unidirectional effect of the indicators on the phenomenon under consideration, so all factors are divided into 2 groups: incentives aimed at increasing energy independence, and the disincentives restrain it. Using logical analysis, indicators are selected that characterize energy independence. 
Among the main energy saving and energy efficiency measures should be:

- for the industry: implementation of the regulation system of demand for energy for industrial enterprises with significant volumes of consumption; the establishment of the monitoring system, evaluating and report+ing on energy consumption in industry and energy efficiency at the level of an individual company and industry; inclusion in state standards of equipment, materials and constructions, transport methods of indicators of energy efficiency; certification of fuel and energy consuming, energy saving and diagnostic equipment, materials, structures, vehicles, as well as energy resources; bringing normative documents in accordance with the requirements of reducing the energy intensity of material production.

- for the population: conducting energy audit of housing buildings and $100 \%$ installation of accounting facilities that will identify housing problems, formulate plans for energy efficiency measures, identify the cost and payback period; maximum reduction of heat losses (replacement of windows, insulation of walls and ceilings); strict compliance with existing rules and regulations for energy efficiency; the modernization of the heating system and the installation of automatic thermostats in heat supply points and/or batteries for multi-apartment buildings; installation of energy-efficient equipment and its rational use.

At the state level, policy priorities in the field of energy efficiency should be: implementation of a state expert assessment of the energy efficiency of project decisions; creation of a system of financial and economic mechanisms that will ensure the economic interest of producers and users in the efficient use of energy resources; continuation of the information campaign on energy saving, advanced domestic and foreign experience in this field.

The important factor for implementation of the proposed measures is improving legislation on energy efficiency, renewable energy sources and fuels. National documents in the energy sector regulate energy saving, energy efficiency and establish the respective competence of public authorities, giving them the necessary powers. Legislative and regulatory documents in the sphere of energy saving directly concern the issues of reducing the use of energy, practical opportunities for implementation of energy saving measures and mechanisms for their financing.

The development of energy production has a decisive influence on the economy in the state and the standard of living of the population. One of the most important components of welfare in civilized states is to provide citizens and companies with the necessary energy resources. The key to achieving this goal is to become a reliable, economically feasible and environmentally safe meeting the needs of the population and the economy in energy products.

In the modern world, the FER access and availability, the continuity of supply and the efficiency of their use largely determine the sustainability and pace of development of any country.

\section{Conclusions}

The current situation poses the issue of saving energy resources in one line with the key issues of the country's economic security, and the implementation of energy saving measures at all levels of the economic mechanism is determined by the primary task. The timing and qualitative problem solving make the functioning and even survival of the entire country dependent on this task (e.g. Hilorme, T., Nazarenko Inna, Okulicz-Kozaryn, W., Getman, O. \& Drobyazko, S. (2018); Mishenin, Y., Koblianska, I., Medvid, V., Maistrenko, Y. (2018)). The formation of plans and strategies of national development in the conditions of functioning of market relations involves the use of scientifically grounded forecasting of the main indicators that are crucial for the energy independence of the country. Therefore, it is advisable to analyse the dynamics of the main indicators that characterize energy saving and energy efficiency. Based on construction and calculation of statistical models of energy saving and energy efficiency, one has to evaluate possible scenarios of development.

Thus, technological and structural restructuring of the economy, social infrastructure, creation of economic, managerial and legal mechanisms of state policy of the energy efficiency remains strategic directions for 
improving energy efficiency and implementation of energy potential. At the same time, the improvement of the regulatory framework for the effective use of energy resources should be preceded by other measures, expanding the motivational and incentive potential of legislation, in particular: implementation of energyefficient technologies and equipment; stimulating the development of the domestic bioethanol and biodiesel market, encouraging enterprises using renewable energy sources; improvement of the mechanisms of state regulation and state control in the field of energy efficiency.

By implementing these directions of energy efficiency development, the qualitative and quantitative indicators will increase significantly, which will lead to the growth of economic indicators of the country and, accordingly, the achievement of an acceptable level of energy independence of the country.

Thus, the basic concepts of statistical provision of regulation of the country's energy independence have been determined. It covers a set of sources of statistical information, a system of indicators of the energy complex, statistical research methods, the use of which allows for a systematic analysis of energy independence, to evaluate its effectiveness, to perform modelling and forecasting in the future, and to formulate managerial decisions, aimed at achieving an acceptable level of energy independence in the future.

The development of measures to counteract negative processes in the energy sector requires an appropriate statistical instrument for regulating energy independence, which will allow reaching a certain level of energy independence of the country and bring it to a new level of development. Statistical support is based on statistical methodology as a set of principles and methods of statistical research, the formation of a system of indicators on their basis, the justification of rules, approaches and methods for analyzing phenomena, and the development of forecasting models.

Based on the analysis of different approaches to the study of energy independence, its concept has been generalized, as well as the role of energy independence in ensuring the national security of the country. Energy independence as one of the components of energy security is a key place in the system of national security of the state, which requires a comprehensive theoretical and methodological justification for evaluation its level, taking into account interdependence and interaction with other indices and indicators of energy and economic security.

Energy independence of the state as a component of energy security is a complex socioeconomic category, characterized by a complex of statistical indicators, the level of state independence in conducting an energy policy that is able to withstand external and internal challenges through intensive measures of economic development without harming society and national production as a whole. The complex of statistical indicators of energy independence includes the efficiency of the FER use, the volume of attracted investments, the state of logistics, import dependence from other countries, the volume of FER production and consumption, etc.

The main indicators of the energy independence evaluation were determined: GDP per capita; production of energy materials; FER import and export; investments in fixed capital for type of economic activity "Electric power, gas, vapour, and conditioned air supply"; volume of industrial products sold by types of economic activity "Electric power, gas, vapour, and conditioned air supply"; total FER consumption in the country; energy intensity of production; the level of FER import to GDP; specific gravity of natural gas in the structure of FER consumption; the degree of wear of fixed-capital assets by types of economic activity "Electric power, gas, vapour, and conditioned air supply".

Thus, the study allowed a comprehensive analysis of such a category as energy independence and to identify the weaknesses and potential for further development of the energy complex of the country. The analysis provided an opportunity to develop practical recommendations for improving energy independence, the implementation of which may bring the energy complex of the country to a qualitatively new level of development. 


\section{References}

Aitzhan, N. Z., \& Svetinovic, D. (2018). Security and privacy in decentralized energy trading through multi-signatures, blockchain and anonymous messaging streams. IEEE Transactions on Dependable and Secure Computing, 15(5), 840-852. URL: https://ieexplore. ieee.org/abstract/document/7589035

Augutis, J., Krikštolaitis, R., Martišauskas, L., Pečiulyte, S., \& Žutautaitė, I. (2017). Integrated energy security assessment. Energy, 138, 890-901. URL: https://www.sciencedirect.com/science/article/abs/pii/S0360544217312914

Bakhtiyari, Z., Yazdanpanah, M., Forouzani, M., \& Kazemi, N. (2017). Intention of agricultural professionals toward biofuels in Iran: Implications for energy security, society, and policy. Renewable and Sustainable Energy Reviews, 69, 341-349. URL: https://www. sciencedirect.com/science/article/pii/S1364032116308942

Biresselioglu, M. E., Yelkenci, T., Ozyorulmaz, E., \& Yumurtaci, I. Ö. (2017). Interpreting Turkish industry’s perception on energy security: A national survey. Renewable and Sustainable Energy Reviews, 67, 1208-1224. URL: https://www.sciencedirect.com/science/ article/pii/S2214629617300774

Bompard, E., Carpignano, A., Erriquez, M., Grosso, D., Pession, M., \& Profumo, F. (2017). National energy security assessment in a geopolitical perspective. Energy, 130, 144-154. URL: https://www.sciencedirect.com/science/article/abs/pii/S0360544217306746

Cox, E. (2018). Assessing long-term energy security: The case of electricity in the United Kingdom. Renewable and Sustainable Energy Reviews, 82, 2287-2299. URL: https://www.sciencedirect.com/science/article/pii/S1364032117312261

Dannreuther, R. (2018). Energy security in Central and Eastern Europe: An IR theoretical framework. URL: https://westminsterresearch. westminster.ac.uk/item/q5180/energy-security-in-central-and-eastern-europe-an-ir-theoretical-framework

García-Gusano, D., Iribarren, D., \& Garraín, D. (2017). Prospective analysis of energy security: A practical life-cycle approach focused on renewable power generation and oriented towards policy-makers. Applied energy, 190, 891-901. URL: https://www.sciencedirect. com/science/article/pii/S0306261917300120

Gil'orme, T., Ryzhyk, Y., \& Yaresko, A. (2016). Formation of the mechanism of energy efficiency management on the basis of 'predatorprey'concept. Problems of development modern science: Theory and practice: Collection of scientific articles. EDEX, Madrid, España, 107-110. URL: http://conf.at.ua/27.07.2016_ispanija.pdf\#page=107

Global Energy Statistical Yearbook 2017. URL: https://yearbook.enerdata.net

Glynn, J., Chiodi, A., \& Gallachóir, B. Ó. (2017). Energy security assessment methods: Quantifying the security co-benefits of decarbonising the Irish Energy System. Energy Strategy Reviews, 15, 72-88. URL: https://www.sciencedirect.com/science/article/pii/ S2211467X16300621

Hilorme, T., Nazarenko Inna, Okulicz-Kozaryn, W., Getman, O. \& Drobyazko, S. (2018). Innovative model of economic behavior of agents in the sphere of energy conservation. Academy of Entrepreneurship Journal, Volume 24, Issue 3, 2018. URL: https://www. abacademies.org/journals/month-september-year-2018-vol-24-issue-3-journal-aej-past-issue.html

Kirshner, J. (2018). The Cult of Energy Insecurity and the Crisis of Energy Security. International Security, 42(4), 170-204. URL: https://www.tobinproject.org/sites/tobinproject.org/files/assets/Kirshner_Cult_Energy_Insecurity.pdf

Nakashydze, L., \& Gil'orme, T. (2015). Energy security assessment when introducing renewable energy technologies. Eastern-European Journal of Enterprise Technologies, 4/8(76), 54-59. URL: http://nbuv.gov.ua/UJRN/Vejpte_2015_4\%288\%29_10

Nitibaskara, T. R. R., Herdiansyah, H., \& Sari, R. (2017, October). The Model of Gas Supply Capacity Simulation In Regional Energy Security Framework: Policy Studies PT. X Cirebon Area. In IOP Conference Series: Earth and Environmental Science (Vol. 88, No. 1, p. 012029). IOP Publishing. URL: http://iopscience.iop.org/article/10.1088/1755-1315/88/1/012029/meta

Radovanović, M., Filipović, S., \& Pavlović, D. (2017). Energy security measurement-A sustainable approach. Renewable and Sustainable Energy Reviews, 68, 1020-1032. URL: https://www.sciencedirect.com/science/article/pii/S1364032116002185

Rogalev, A., Komarov, I., Kindra, V., Zlyvk, O. (2018). Entrepreneurial assessment of sustainable development technologies for power energy sector. Enterpreneurship and Sustainability Issues 6(1): 429-445. http://doi.org/10.9770/jesi.2018.6.1(26)

Su, M., Zhang, M., Lu, W., Chang, X., Chen, B., Liu, G., ... \& Zhang, Y. (2017). ENA-based evaluation of energy supply security: Comparison between the Chinese crude oil and natural gas supply systems. Renewable and Sustainable Energy Reviews, $72,888-899$. URL: https://www.sciencedirect.com/science/article/pii/S1364032117301466

Tetiana, H., Chorna M., Karpenko L., Milyavskiy M. \& Drobyazko S. (2018). Innovative model of enterprises personnel incentives 
evaluation. Academy of Strategic Management Journal. Volume 17, Issue 3, 2018 URL: https://www.abacademies.org/journals/monthjune-year-2018-vol-17-issue-3-journal-asmj-past-issue.html

Karpenko, L., Serbov, M., Kwilinski, A., Makedon, V. \& Drobyazko, S. (2018). Methodological platform of the control mechanism with the energy saving technologies, Academy of Strategic Management Journal, Volume 17, Issue 5, 2018: URL: https://www.abacademies. org/articles/Methodological-platform-of-the-control-mechanism-1939-6104-17-5-271.pdf

Lakhno, V., Malyukov, V., Bochulia, T., Hipters, Z., Kwilinski, A. \& Tomashevska, O. (2018). Model of managing of the procedure of mutual financial investing in information technologies and smart city systems, International Journal of Civil Engineering and Technology 9(8), 1802-1812. URL: http://www.iaeme.com/MasterAdmin/UploadFolder/IJCIET_09_08_181/IJCIET_09_08_181.pdf

Mazurkiewicz, J., Lis, P. (2015). Ocena bezpieczeństwa energetycznego w wybranych krajach Unii Europejskiej [The assessment of energy security in selected European Union countries], Rynek Energii 4(119): 11-20. URL: https://www.researchgate.net/ profile/Piotr_Lis/publication/281110415_Ocena_bezpieczenstwa_energetycznego_w_wybranych_krajach_Unii_Europejskiej/ links/55e07b7508ae2fac471baf2d/Ocena-bezpieczenstwa-energetycznego-w-wybranych-krajach-Unii-Europejskiej.pdf

Mishenin, Y., Koblianska, I., Medvid, V., Maistrenko, Y. (2018). Sustainable regional development policy formation: role of industrial ecology and logistics. Enterpreneurship and Sustainability Issues 6(1): 329-341. http://doi.org/10.9770/jesi.2018.6.1(20)

Pająk, K., Kvilinskyi, O., Fasiecka, O., Miśkiewicz, R. (2017). Energy security in regional policy in Wielkopolska region of Poland, Economics and Environment 2(61): 122-138. URL: https://www.ekonomiaisrodowisko.pl/uploads/eis\%2061/11_pajak.pdf

Smaliukiene, R.; Monni, S. 2019. A step-by-step approach to social marketing in energy transition, Insights into Regional Development 1(1): 19-32. http://doi.org/10.9770/IRD.2019.1.1(2)

Tetiana, H., Karpenko, L., Fedoruk, O., Shevchenko, I., \& Drobyazko, S. (2018). Innovative methods of performance evaluation of energy efficiency project. Academy of Strategic Management Journal, 17(2), 112-110. URL: https://www.abacademies.org/articles/ innovative-methods-of-performance-evaluation-of-energy-efficiency-projects-7067.html

Valdés, J. (2018). Arbitrariness in multidimensional energy security indicators. Ecological Economics, 145, 263-273. URL: https:// www.sciencedirect.com/science/article/pii/S0921800916312484

Wang, Q., \& Zhou, K. (2017). A framework for evaluating global national energy security. Applied energy, 188, 19-31. URL: https:// www.sciencedirect.com/science/article/pii/S0306261916317470

\section{Short biographical note about the contributors at the end of the article:}

Henryk DŹWIGOL, Dr. Hab. (Economics), Professor, Faculty of Organization and Management, Silesian University of Technology ORCID ID: orcid.org/0000-0002-2005-0078

Mariola DŹWIGOL-BAROSZ, Ph.D. (Economics), Associate Professor, Faculty of Organization and Management, Silesian University of Technology

ORCID ID: orcid.org/0000-0002-5306-3836

Zinaida ZHYVKO, Lviv State University of Internal Affairs, Head of the Department of Management, Doctor of Science in Economics, Professor

ORCID ID: orcid.org/0000-0002-4045-669X

Radosław MIŚKIEWICZ, Ph.D. (Economics), Associate Professor, Faculty of Organization and Management, Silesian University of Technology

ORCID ID: orcid.org/0000-0003-2370-4783

Halyna PUSHAK, PhD (Economics), Associate Professor, Department of Theoretical and Applied Economics, Lviv Polytechnic National University

ORCID ID: orcid.org/0000-0002-2487-8374

Register for an ORCID ID:

https://orcid.org/register

This work is licensed under the Creative Commons Attribution International License (CC BY). http://creativecommons.org/licenses/by/4.0/ 